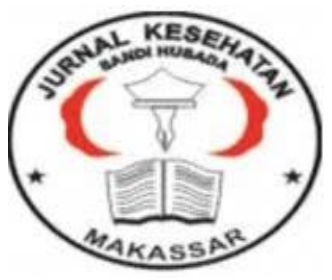

Jurnal Ilmiah Kesehatan Sandi Husada

hhttps://akper-sandikarsa.e-journal.id/JIKSH

Volume 9, Nomor 2, Desember 2020, pp 753-760

p-ISSN: 2354-6093 dan e-ISSN: 2654-4563

DOI: $10.35816 /$ jiskh.v10i2.392

\title{
Peran Leptin Terhadap Tes Toleransi Glukosa Oral pada Penderita DM Tipe 2
}

Role of Leptin on Oral Glucose Tolerance Test in Type 2 DM Patients

Catur Ambar Wati

Fakultas Kedokteran, Universitas Lampung

\section{Artikel info}

\section{Artikel history:}

Received; Juli 2020

Revised: Agustus 2020

Accepted; Agustus 2020

\begin{abstract}
Abstrak
Latar Belakang: DM merupakan suatu kelompok penyakit metabolik dengan karakteristik hiperglikemia yang terjadi karena kelainan sekresi insulin, kerja insulin atau keduaduanya. Gejala yang dikeluhkan pada penderita Diabetes Melitus yaitu polidipsi, poliuri, polifagia, penurunan berat badan, dan kesemutan. Tes toleransi glukosa oral merupakan tes yang digunakan untuk menegakkan diagnosis DM saat level glukosa darah kurang tegas, saat kehamilan, atau untuk skrining DM maupun TGT. Leptin merupakan hormon yang diproduksi oleh sel lemak yang meregulasi penimbunan lemak di tubuh dan menyesuaikan antara rasa lapar dengan pengeluaran energi.Tujuan: mengetahui lebih lanjut tentang peran leptin terhadap TTGO pada penderita DM Tipe 2 Metode: Menggunakan studi literatur dari jurnal baik nasional maupun internasional untuk menambah pengetahuan dan pemahaman mengenai topik yang dibahas dengan cara meringkas topik pembahasan dan membandingkan hasil yang disajikan dalam artikel. Hasil: Leptin terhadap pemeriksaan TTGO pada individu dengan toleransi glukosa terganggu berpeluang lebih besar menjadi diabetes melitus apabila tidak ada intervensi pada gaya hidupnya. Kesimpulan: Leptin berperan terhadap pemeriksan TTGO pada penderita DM Tipe 2.
\end{abstract}

Abstract

Background: DM is a group of metabolic diseases characterized by hyperglycemia that occurs due to abnormal insulin secretion, insulin action or both. Symptoms that are complained of in diabetes mellitus sufferers are polydipsi, polyuria, polyphagia, weight loss, and tingling sensation. The oral glucose tolerance test is a test used to diagnose DM when the blood glucose level is less firm, during pregnancy, or to screen for DM or TGT. Leptin is a hormone produced by fat cells that regulates fat storage in the body 
and adjusts hunger to energy expenditure. Objective: to find out more about the role of leptin on TTGO in people with Type 2 diabetes. Methods: using literature studies from both national and international journals to increase knowledge and understanding of the topics discussed by summarizing the discussion topics and comparing the results presented in the article. Results: Leptin on TTGO examination in individuals with impaired glucose tolerance had a greater chance of becoming diabetes mellitus if there was no intervention in their lifestyle. Conclusion: Leptin plays a role in checking TTGO in people with Type 2 diabetes.

\begin{tabular}{l}
\hline Keywords: \\
Leptin; \\
Oral Glucose Tolerance; \\
DM Tipe 2;
\end{tabular}

Coresponden author:

Email: caturambarw9@gmail.com

artikel dengan akses terbuka dibawah lisensi CC BY 4.0

\section{Pendahuluan}

DM merupakan suatu kelompok penyakit metabolik dengan karakteristik hiperglikemia yang terjadi karena kelainan sekresi insulin, kerja insulin atau kedua-duanya. Gejala yang dikeluhkan pada penderita Diabetes Melitus yaitu polidipsi, poliuri, polifagia, penurunan berat badan, dan kesemutan (Buraerah, 2010). Diabetes Melitus ditegakkan berdasarkan pemeriksaan kadar glukosa darah (PERKENI, 2015). Tes toleransi glukosa oral merupakan tes yang digunakan untuk menegakkan diagnosis DM saat level glukosa darah kurang tegas, saat kehamilan, atau untuk skrining DM maupun TGT. Subyek yang akan melakukan pemeriksaan TTGO tetap makan seperti kebiasaan sehari-hari dan tetap melakukan kegiatan jasmani seperti biasa tiga hari sebelum pemeriksaan. Subyek yang diperiksa harus berpuasa setidaknya selama 10-12 jam yang dapat dimulai pada malam hari, namun tetap diperbolehkan minum air putih tanpa gula. Subyek kemudian akan diperiksa GDP-nya pada pagi hari setelah puasa. Selanjutnya subyek diberikan glukosa 75 gram (orang dewasa) yang dilarutkan ke dalam air $250 \mathrm{~mL}$ dan diminum dalam waktu 5 menit. Pasien diharuskan berpuasa kembali sampai pengambilan sampel darah 2 jam setelahnya. Selama proses pemeriksaan ini, subyek yang diperiksa tetap beristirahat dan tidak merokok (Purnamasari, 2014 \& Henry et al., 2016). Penilaian adalah sebagai berikut: 1) Glukosa normal apabila $\leq 140 \mathrm{mg} / \mathrm{dl}$; 2) Toleransi Glukosa Terganggu (TGT) apabila kadar glukosa > $140 \mathrm{mg} / \mathrm{dL}-199 \mathrm{mg} / \mathrm{dl}$; dan 3) Diabetes Melitus apabila $\geq 200 \mathrm{mg} / \mathrm{dL}$ (Hardjoeno, 2007).

International Diabetes Federation(IDF) menyebutkan bahwa prevalensi Diabetes Melitus di dunia adalah 1,9\% dan telah menjadikan DM sebagai penyebab kematian urutan ke tujuh di dunia. Sedangkan tahun 2012 angka kejadian diabetes melitus di dunia sebanyak 371 juta jiwa dimana proporsi kejadian diabetes melitus tipe 2 adalah 95\% dari populasi dunia yang menderita diabetes mellitus. Hasil Riset Kesehatan Dasar pada tahun 2008, menunjukan prevalensi DM di Indonesia membesar sampai 57\%. Tingginya prevalensi Diabetes Melitus tipe 2 disebabkan oleh faktor risiko yang tidak dapat berubah misalnya jenis kelamin, umur, dan faktor genetik yang kedua adalah faktor risiko yang dapat diubah misalnya kebiasaan merokok tingkat pendidikan, pekerjaan, aktivitas fisik, kebiasaan merokok, konsumsi alkohol, Indeks Masa Tubuh, lingkar pinggang dan umur (Fatimah, 2015). Menurut Friedman (2009) pada Nikmah dan Dany (2017) menyatakan bahwa marker prediktor DM yang berhubungan dengan DM tipe 2 dapat berupa protein yaitu 
leptin dan interleukin. Jaringan lemak yang menumpuk akan menghasilkan hormon adipositokin seperti leptin dan adiponektin atau sitokin proinflamatori interleukin.

Leptin merupakan hormon yang diproduksi oleh sel lemak yang meregulasi penimbunan lemak di tubuh dan menyesuaikan antara rasa lapar dengan pengeluaran energi. Rasa lapar dihambat saat timbunan lemak mencapai level tertentu, leptin kemudian disekresikan dan bersirkulasi dalam tubuh dan mengaktivasi reseptor leptin di hipotalamus. Pengeluaran energi meningkat oleh adanya sinyal dari otak dan secara langsung melalui reseptor leptin pada target peripheral (Sharifi, 2013). Leptin juga meregulasi proses fisiologik dan tingkah laku yang mencakup nafsu makan, berat badan, fungsi neuroendokrin dan glikemia. Efeknya adalah mediasi melalui aktifitas reseptor leptin (LepRs) yang diekspresikan oleh sistim syaraf pusat (Nikmah dan Dany, 2017).

Apabila asupan energi melebihi dari yang dibutuhkan, maka jaringan adiposa meningkat disertai dengan peningkatan kadar leptin dalam peredaran darah. Kemudian, leptin merangsang anorexigenic center di hipotalamus agar menurunkan produksi Neuropeptida Y (NPY) sehingga terjadi penurunan nafsu makan. Apabila kebutuhan energi lebih besar dari asupan energi, maka jaringan adiposa berkurang dan terjadi rangsangan pada orexigenic center di hipotalamus yang menyebabkan peningkatan nafsu makan. Pada sebagian besar penderita obesitas terjadi resistensi leptin, sehingga tingginya kadar leptin tidak menyebabkan penurunan nafsu makan (Jeffrey, 2009). Diabetes melitus merupakan penyakit yang disebabkan oleh kurangnya atau ketidakmampuan pankreas sama sekali dalam memproduksi insulin di dalam darah, untuk menerapkan pola hidup sehat sebagai salah satu cara untuk mengurangi risiko terjadinya diabetes mellitus (Irwansyah \& Kasim, 2020).

Leptin dalam darah berhubungan dengan marker massa lemak tubuh sedangkan obesitas dikenal sebagai faktor risiko terjadinya penyakit kardiovaskuler dan diabetes tipe 2, sehingga leptin merupakan mediator kandidat peningkatan risiko ini. Pada penelitian di Saudi Arabia menyebutkan bahwa kadar leptin pada penderita diabetes dan prediabetes lebih tinggi dibandingkan dengan normoglikemik namun tidak berhubungan dengan ukuran obesitasnya. Pada masyarakat Saudi Arabia yang merupakan negara timur tengah seiring dengan peningkatan ekonomi dan perubahan budaya sekitar 30 tahun terakhir, hampir 60\% merupakan populasi urban dan mengadopsi 'westernised lifestyle' pada pola makan dan aktivitas fisik. Obesitas dan metabolik sindrom meningkat sehingga setidaknya menjelaskan adanya peningkatan insiden penyakit jantung koroner. Penelitian ini juga menemukan adanya hubungan positif antara leptin dan lingkar pinggul pada penderita prediabetes (Al-Daghri, 2007)

\section{Metode}

Metode yang digunakan oleh penulis adalah studi literatur dari berbagai jurnal nasional maupun internasional. Studi literature merupakan suatu penelusuran dan penelitian kepustakaan dengan membaca berbagai buku, jurnal, dan terbitan-terbitan lain yang berkaitan dengan topik penelitian, untuk menghasilkan satu tulisan berkenaan dengan satu topik atau isyu tertentu. Studi Literatur akan menjelajahi kajian-kajian yang pernah dilakukan orang tentang satu topik atau isyu ter-tentu. Metode ini digunakan dengan tujuan untuk menambah pengetahuan dan pemahaman mengenai topik yang dibahas dengan menyajikan materi yang telah diterbitkan serta memberikan informasi fakta atau analisis baru dari tinjauan literatur yang relevan kemudian membandingkan hasil tersebut dalam artikel. 


\section{Hasil Dan Pembahasan}

Diabetes Melitus merupakan suatu penyakit menahun yang ditandai oleh kadar glukosa darah melebihi normal dan gangguan metabolisme karbohidrat, lemak dan protein yang disebabkan oleh kekurangan hormon insulin secara relative maupun absolut. Bila hal ini dibiarkan tidak terkendali dapat terjadi komplikasi metabolik akut maupun komplikasi vaskuler jangka panjang, baik mikroangiopati maupun makroangiopati (Erwan dan Kadir, 2014). Diabetes Mellitus Tipe 2 adalah penyakit gangguan metabolik yang di tandai oleh kenaikan gula darah akibat penurunan sekresi insulin oleh sel beta pankreas dan atau ganguan fungsi insulin (resistensi insulin) (Depkes, 2005). Terdapat beberapa keadaan yang berperan dalam patofifiologi DM Tipe 2, yaitu resistensi insulin dan disfungsi sel $\beta$ pancreas. Diabetes melitus tipe 2 bukan disebabkan oleh kurangnya sekresi insulin, namun karena sel sel sasaran insulin gagal atau tidak mampu merespon insulin secara normal.Keadaan ini lazim disebut sebagai "resistensi insulin" (Teixeria, 2011).

Resistensi insulin banyak terjadi akibat obesitas dan kurangnya aktivitas fisik serta penuaan. Pada penderita diabetes melitus tipe 2 dapat juga terjadi produksi glukosa hepatik yang berlebihan namun tidak terjadi kerusakan sel-sel $\beta$ langerhans secara autoimun seperti diabetes melitus tipe 2. Defisiensi fungsi insulin pada penderita diabetes melitus tipe 2 hanya bersifat relatif dan tidak absolut (Hastuti, 2008 dan Harding, 2003). Menurut hasil penelitian (Sari, dkk, 2020) Gestational Diabetes Mellitus (DMG) adalah intoleransi kadar glukosa darah selama kehamilan. Salah satu metode yang dapat dilakukan untuk membantu diagnosis diabetes melitus adalah dengan melakukan tes persetujuan persetujuan lisan (TTGO). Deskripsi Tes Toleransi Glukosa Oral pada ibu hamil trimester II dan III Hasil tes ibu hamil trimester II dan III sebanyak 30 responden memiliki GDP <95 mg / dl dan TTGO <125mg / dl (100\%). Umur <35 tahun sebanyak 15 orang $(100 \%)$ dan 14 orang $(93,3 \%)$. BMI trimester II normal sebanyak 13 orang $(86,7 \%)$ dan trimester III 14 orang (93,3\%), statistik paritas ibu hamil trimester II dan III bersifat primipara sebanyak 7 orang $(46,7 \%)$. memiliki tekanan darah normal 14 orang $(93,3 \%)$, dan 13 orang (86,7\%). Melakukan Tes Toleransi Glukosa Oral (TTG0) pada ibu hamil dapat membantu meningkatkan keselamatan ibu baik selama kehamilan maupun sesudah kehamilan.

Pada awal perkembangan diabetes melitus tipe 2 , sel $\beta$ menunjukan gangguan pada sekresi insulin fase pertama, artinya sekresi insulin gagal mengkompensasi resistensi insulin. Apabila tidak ditangani dengan baik, pada perkembangan selanjutnya akan terjadi kerusakan sel-sel $\beta$ pankreas. Kerusakan sel-sel $\beta$ pankreas akan terjadi secara progresif dan seringkali akan menyebabkan defisiensi insulin, sehingga akhirnya penderita memerlukan insulin eksogen. Pada penderita diabetes melitus tipe 2 memang umumnya ditemukan kedua faktor tersebut, yaitu resistensi insulin dan defisiensi insulin (Fatimah, 2015).

Peningkatan jumlah penderita DM tipe 2, berkaitan dengan beberapa faktor yaitu faktor risiko yang tidak dapat diubah, faktor risiko yang dapat diubah dan faktor lain. Menurut American Diabetes Association (ADA) bahwa DM berkaitan dengan faktor risiko yang tidak dapat diubah meliputi riwayat keluarga dengan DM (first degree relative), umur $\geq 45$ tahun, etnik, riwayat melahirkan bayi dengan berat badan lahir bayi $>4000$ gram atau riwayat pernah menderita DM gestasional dan riwayat lahir dengan berat badan rendah $(<2,5 \mathrm{~kg})$ (Bannet, 2008 dan Wild, 2004). Faktor risiko yang dapat diubah meliputi obesitas berdasarkan IMT $\geq 25 \mathrm{~kg} / \mathrm{m} 2$ atau lingkar perut $\geq 80 \mathrm{~cm}$ pada wanita dan $\geq 90 \mathrm{~cm}$ pada laki-laki, kurangnya aktivitas fisik, hipertensi, dislipidemi dan diet tidak sehat (Waspadji, 2009). 
Faktor lain yang terkait dengan risiko diabetes adalah penderita polycystic ovarysindrome (PCOS), penderita sindrom metabolic memiliki riwatyat toleransi glukosa terganggu (TGT) atau glukosa darah puasa terganggu (GDPT) sebelumnya, memiliki riwayat penyakit kardiovaskuler seperti stroke, PJK, atau peripheral rrterial Diseases (PAD), konsumsi alkohol, faktor stres, kebiasaan merokok, jenis kelamin, konsumsi kopi dan kafein (Buraerah, 2010).

Gejala diabetes melitus dibagi menjadi, yaitu akut dan kronik. Gejala akut diabetes melitus yaitu : Poliphagia (banyak makan), Polidipsia (banyak minum), Poliuria (banyak kencing/sering kencing di malam hari), nafsu makan bertambah namu berat badan turun dengan cepat (5-10 kg dalam waktu 2-4 minggu), dan mudah lelah (Fatimah, 2015). Gejala kronik diabetes melitus yaitu : Kesemutan, kulit terasa panas atau seperti tertusuk tusuk jarum, rasa kebas di kulit, kram, kelelahan, mudah mengantuk, pandangan mulai kabur, gigi mudah goyah dan mudah lepas, kemampuan seksual menurun bahkan pada pria bisa terjadi impotensi, pada ibu hamil sering terjadi keguguran atau kematian janin dalam kandungan atau dengan bayi berat lahir lebih dari 4kg (Fatimah, 2015).

Diagnosis DM dapat dilakukan dengan pemeriksaan Tes Toleransi Glukosa Oral (TTGO). Tes toleransi glukosa oral merupakan tes yang digunakan untuk menegakkan diagnosis DM saat level glukosa darah kurang tegas, saat kehamilan, atau untuk skrining DM maupun TGT. Subyek yang akan melakukan pemeriksaan TTGO tetap makan seperti kebiasaan sehari hari dan tetap melakukan kegiatan jasmani seperti biasa tiga hari sebelum pemeriksaan. Subyek yang diperiksa harus berpuasa setidaknya selama 10-12 jam yang dapat dimulai pada malam hari, namun tetap diperbolehkan minum air putih tanpa gula. Subyek kemudian akan diperiksa GDP-nya pada pagi hari setelah puasa. Selanjutnya subyek diberikan glukosa 75 gram (orang dewasa) yang dilarutkan ke dalam air $250 \mathrm{~mL}$ dan diminum dalam waktu 5 menit. Pasien diharuskan berpuasa kembali sampai pengambilan sampel darah 2 jam setelahnya. Selama proses pemeriksaan ini, subyek yang diperiksa tetap beristirahat dan tidak merokok. Hasil pemeriksaan glukosa darah 2 jam pasca pembebanan dibagi menjadi 3 yaitu: 1) Glukosa normal apabila $\leq$ $140 \mathrm{mg} / \mathrm{dl}$; 2) Toleransi Glukosa Terganggu (TGT) apabila kadar glukosa $>140 \mathrm{mg} / \mathrm{dL}$ 199 mg/dl; dan 3) Diabetes Melitus apabila $\geq 200$ mg/dL (Purnamasari, 2014 dan Henry et al, 2016).

Marker prediktor DM yang berhubungan dengan DM tipe 2 dapat berupa protein yaitu leptin dan interleukin. Jaringan lemak yang menumpuk akan menghasilkan hormon adipositokin seperti leptin dan adiponektin atau sitokin proinflamatori interleukin (Friedman, 2009). Menurut penelitian kadar leptin dipengaruhi aktifitas fisik yang dilakukan oleh Nikmah dan Dany (2017) menyatakan bahwa IMT berisiko (IMT >23) memiliki kadar leptin yang lebih tinggi dibandingkan dengan IMT normal (IMT $<18,5$ $22,9)$. Persentase yang diperoleh memiliki perbedaan cukup besar dengan nilai odds ratio yang besar pula yaitu responden dengan IMT berisiko 4,61 x memiliki kadar leptin lebih tinggi dibanding dengan IMT normal. Sedangkan seluruh responden dengan IMT berisiko, responden dengan DM dan TGT memiliki risiko 2,3 x akan memiliki kadar leptin lebih tinggi dibandingkan dengan responden normal.

Individu dengan obesitas memiliki kadar leptin tinggi, karena memiliki sel lemak yang sangat banyak sehingga produksi leptin juga banyak. Namun orang obes seringkali gagal mengontrol rasa lapar dan sulit membatasi asupan makanannya, kondisi ini disebut dengan resistensi leptin. Penyebab terjadinya resistensi leptin adalah insulin (Manaf, 2013). Hormon insulin bertugas mengubah gula menjadi energi, jika berlebih akan berubah menjadi lemak dan tubuh mengeluarkan insulin sesuai kondisi asupan glukosa yang masuk ke dalam tubuh. Glukosa yang semakin banyak akan menstimuli pankreas 
untuk menghasilkan lebih banyak insulin, sehingga semakin banyak pula lemak terbentuk. Kondisi tubuh yang memproduksi insulin banyak, menyebabkan tubuh tidak lagi merespon sehingga terjadi resistensi insulin. Resistensi insulin akan menyebabkan terhalangnya pula kinerja leptin menghantarkan sinyal kenyang ke otak, karena sel tidak menerima glukosa oleh kinerja insulin, sehingga tubuh menganggap masih butuh energi dan terus merasakan lapar (Manaf, 2013).

Hormon leptin dikeluarkan kedalam system sirkulasi oleh jaringan adiposa. Serum dan plasma leptin tertinggi terdapat pada orang yang memiliki IMT tertinggi, namun kadarnya di dalam tubuh dipengaruhi oleh berbagai faktor. Faktor tersebut adalah sediaan energi, asupan makanan, gender, umur, olahraga serta serapan glukosa. Kadar leptin pada wanita lebih tinggi dibandingkan pada pria dan semakin menurun pengaruhnya ketika usia menua. Leptin juga mengatur metabolism pemecahan lemak, yang seiring dengan peningkatan kadar leptin maka metabolism tubuh juga meningkat. Secara keseluruhan, fungsi utama leptin adalah menghambat nafsu makan, menstimulasi termogenesis, meningkatkan oksidasi asam lemak, menurunkan glukosa, dan menurunkan berat badan dan lemak (Zyriax et al, 2013). Buah naga memiliki efek menurunkan kadar glukosa darah pada penderita diabetes mellitus tipe 2 karena mengandung serat yang mampu mengikat air dalam usus, serta mengandung antioksidan dan senyawa bioaktif serta mampu menghambat senyawa radikal bebas (Ayuni, 2020).

Hasil penelitian menunjukkan responden dengan DM dan TGT memiliki kadar leptin yang lebih tinggi 2,3 kali dibandingkan dengan responden normal. Hasil penelitian juga menunjukkan bahwa kadar leptin pada responden DM sebanding dengan responden TGT dengan kadar rata-rata responden TGT lebih tinggi sedikit. Hal ini dikarenakan pada responden yang telah mengalami DM dalam beberapa tahun terakhir biasanya akan mengalami penyesuaian berat badan dan cenderung mengalami penurunan berat badan, sehingga kadar leptin ikut menurun. Hal yang berbeda terjadi pada responden TGT yang sedang mengalami peningkatan berat badan yang otomatis kadar leptinnya meningkat. Jika responden TGT tidak hati-hati dalam menjaga asupan makanan ke dalam tubuh, kemungkinan menjadi diabetes sangat tinggi. Karena sudah terdapat dua tanda adanya ketidakseimbangan metabolisme dalam tubuh, yaitu adanya kadar glukosa dan kadar leptin yang melebihi batas normal. Dalam tubuh responden TGT sudah mulai mengalami resistensi leptin yang diakibatkan oleh insulin yang mengirim sinyal bahwa tubuh kelebihan energi dan mengubah energi menjadi cadangan lemak tubuh karena dianggap masih terus membutuhkan energi (Zimmet et al, 1998)

Hal yang berbeda terjadi pada responden dengan kadar glukosa normal yang memiliki kadar leptin normal. Responden dengan glukosa darah normal masih memiliki respon tubuh yang bagus terhadap asupan makanan ke dalam tubuh, ditandai oleh produksi hormon insulin dan leptin masih bersinergi dengan respon di otak dalam menjaga keseimbangan kebutuhan energi. Keseimbangan kebutuhan energi akan menjaga berat badan tubuh yang stabil dengan IMT normal (Nikmah dan Dany, 2017). Pada penelitian tersebut diketahui gambaran leptin pada individu dengan toleransi glukosa terganggu, memiliki peluang yang besar untuk menjadi diabetes, dengan gambaran leptin yang sebanding dengan individu DM. Maka dapat disimpulkan bahwa individu dengan toleransi glukosa terganggu memiliki peluang besar untuk menjadi diabetes jika tidak ada intervensi pada gaya hidupnya (Nikmah dan Dany, 2017). Hasil tersebut sesuai dengan penelitian yang dilakukan oleh Snijder bahwa leptin yang merupakan marker lemak tubuh, memiliki kadar lebih tinggi pada responden dengan berat badan lebih dan didukung dengan kadar gula darah tinggi pada responden DM dan TGT (Snijder et al, 2006). 


\section{Simpulan Dan Saran}

Diabetes Melitus Tipe 2 adalah penyakit gangguan metabolik yang di tandai oleh kenaikan gula darah akibat penurunan sekresi insulin oleh sel beta pankreas dan atau ganguan fungsi insulin (resistensi insulin). Diagnosis DM dapat dilakukan dengan pemeriksaan Tes Toleransi Glukosa Oral (TTGO). Tes toleransi glukosa oral merupakan tes yang digunakan untuk menegakkan diagnosis DM saat level glukosa darah kurang tegas, saat kehamilan, atau untuk skrining DM maupun TGT. Marker prediktor DM yang berhubungan dengan DM tipe 2 dapat berupa protein yaitu leptin dan interleukin. Individu dengan IMT berisiko (IMT > 23) memiliki kadar leptin yang lebih tinggi dibandingkan dengan IMT normal (IMT $<18,5-22,9)$. Selain itu kadar leptin yang terdapat pada individu dengan toleransi glukosa terganggu lebih memiliki peluang besar menjadi diabetes apabila tidak ada intervensi pada gaya hidupnya. Hal tersebut dapat disimpulkan bahwa leptin berperan terhadap hasil pemeriksaan TTGO pada penderita DM Tipe 2. Masih perlu dilakukan penelitian lebih lanjut untuk mengetahui peran gen leptin terhadap TTGO pada penderita DM Tipe 2

\section{Daftar Rujukan}

Al-Daghri, NM., et al. (2007). Serum leptin and its relation to anthropometric measures of obesity in pre-diabetic Saudis. Cardiovasc Diabetol [Internet], 6(1), 18.

Ayuni, N. M. (2020). Efek Buah Naga Merah (Hylocereus Polyrhizus) Terhadap Penurunan Kadar Glukosa Darah Pada Diabetes Tipe 2. Jurnal Ilmiah Kesehatan Sandi Husada, 11(1 SE-Articles). https://doi.org/10.35816/jiskh.v11i1.350

Buraerah, H. (2010). Analisis Faktor Risiko Diabetes Melitus tipe 2 di Puskesmas Tanrutedong, Sidenreg Rappan. Jurnal Ilmiah Nasional. Retrived from http://lib.atmajaya.ac.id/default.aspx?tabID= 61\&src=a\&id=186192

Erwan \& Kadir. (2014). Hubungan Antara Obesitas Dan Keturunan Dengan Kejadian Diabetes Mellitus Di Poliklinik Penyakit Dalam Rsud Labuang Baji Makassar. Jurnal Ilmiah Kesehatan Diagnosis, 5(1), 47-52

Fatimah, RN. (2015). Diabetes Melitus Tipe 2, 4(5), 93-101

Friedman, JM. (2009). Leptin at 14 y of age: An ongoing story. Am J Clin Nutr, 89(3), 973979

Harding, Anne Helen et al. (2003). Dietary Fat adn Risk of Clinic Type Diabetes. American Journal of Epidemiology,15(1), 150-159.

Hardjoeno, $\mathrm{H}$ et al. (2007). Interprestasi hasil tes laboratorium diagnostik. Hasanuddin University Press (LEPHASS): Makassar.

Hastuti, RT. (2008). Faktor-faktor Risiko Ulkus Diabetika Pada Penderita Diabetes Melitus Studi Kasus di RSUD Dr. Moewardi Surakarta. [dissertation] Universitas Diponegoro (Semarang)

Henry, JB., McPherson, RA., Pincus, MR. (2016). Henry's clinical diagnosis and management by laboratory methods. Edisi ke-23. Philadelphia: Saunders Elsevier. hlm. 812-34.

Irwansyah, I., \& Kasim, I. (2020). Deteksi Dini Risiko Diabetes Melitus Pada Staff Pengajar Stikes Megarezky Makassar. Jurnal Ilmiah Kesehatan Sandi Husada, 11(1 SEArticles). https://doi.org/10.35816/jiskh.v11i1.343

Jeffrey, A., et al. (2009). Stronger Relationship Between Central Adiposity And C Reactive Protein In Older Women Tahn Men', Source Menopause: 16, 84-89 (Diakses pada: 1 Agustus 2020).

Manaf, A. (2013). Prediabetes. In: Subbagian Endokrin Metabolik, Bagian Ilmu Penyakit Dalam Fakultas Kedokteran Universitas Andalas / RSUP Dr M Jamil Padang. p. 1-8.

Nikmah, UA \& Dany, F. (2017). Kadar Leptin sebagai Petanda Diabetes pada Individu dengan Diabetes dan Toleransi Glukosa Terganggu. Buletin Penelitian Kesehatan, 45(3), 145-152 
Perkumpulan Endokrinologi Indonesia (PERKENI). (2015). Pengelolaan dan Pencegahan Diabetes Melitus Tipe 2 di Indonesia. Jakarta: PB PERKENI. hlm. 11-4.

Purnamasari, D. (2014). Diagnosis dan Klasifikasi Diabetes Melitus. In Setiati dkk (ed). Buku Ajar Ilmu Penyakit Dalam Jilid II Edisi VI. Jakarta: FKUI, : 2323-7.

Sari, N., Octarianingsih, F., Ladyani, F., \& Kurniawan, B. (2020). Tes Toleransi Glukosa Oral pada Ibu Hamil Trimester II Dan III di Puskesmas Rajabasa Bandar Lampung. Jurnal Ilmiah Kesehatan Sandi Husada, 11 (1 SE-Articles). https://doi.org/10.35816/jiskh.v11i1.224

Sharifi, F., Yamini, M., Esmaeilzadeh, A., Mousavinasab, N., Shajari, Z. (2013). Acylated ghrelin and leptin concentrations in patients with type 2 diabetes mellitus, people with prediabetes and first degree relatives of patients with diabetes, a comparative study. J Diabetes Metab Disord [Internet], 12(1), 51

Snijder, MB., Heine, RJ., Seidell, JC., Bouter, LM., Stehouwer, CDA., Nijpels, G., et al. (2006). Associations of adiponectin levels with incident impaired glucose metabolism and type 2 diabetes in older men and women the hoorn study. Diabetes Care, 29(11), 2498-503.

Sudoyo, AW., et al. (2009). Buku Ajar Ilmu Penyakit Dalam, Jilid III, edisi kelima. Jakarta: Interna publishing, h.1961.

Teixeria, L. (2011). Regular physical exercise training assists in preventing type 2 diabetes development: focus on its antioxidant and anti-inflammantory properties. Biomed Central Cardiovascular Diabetology, 10(2), 1-15.

Wild, S., et al. (2004). Global prevalence of diabetes: estimates for the year 2000 and projections for 2030. Diabetic care, 27(3), 1047-1053

Zimmet PZ., et al. (1998). Is there a relationship between leptin and insulin sensitivity independent of obesity? A population-based study in the Indian Ocean nation of Mauritius. Mauritius NCD Study Group. Int J Obes Relat Metab Disord [Internet], 22(2), 171-177.

Zyriax, B., Salazar, R., Hoeppner, W., Vettorazzi, E., Herder, C., Windler, E. (2013). The association of genetic markers for type 2 diabetes with prediabetic status - crosssectional data of a diabetes prevention trial. PLoS One, 8(9), 75807. 